\title{
Conservation status and regional population estimates of the White-breasted Mesite Mesitornis variegata, a rare Malagasy endemic
}

\author{
A. F. A. HAWKINS
}

\section{Summary}

Three different methods (visual detection on transects, call-playback and territory mapping) were used to estimate the densities of the White-breasted Mesite Mesitornis variegata in western Malagasy deciduous forest. The species is threatened and belongs to an endemic family of uncertain affinities. The population in the Menabe region, central-west Madagascar, surveyed using call-playback (the most efficient survey method), is estimated at 3,000-19,000 individuals; that of Ankarafantsika, north-west Madagascar, $6,000-26,000$ individuals. Other western populations may be relicts. The White-breasted Mesite occurs at highest densities and with highest productivity in logged forest near rivers in the south of its range and in undisturbed sand-forest in the north, and is present at low density or absent from some areas of apparently suitable habitat, as well as forest that is secondary or has been severely damaged by burning. It is probably not immediately at risk from rats, dogs or selective exploitation, but hunting and forest burning through accidental bushfires or clearance for agriculture are locally important threats.

Trois méthodes différentes (détection visuelle sur transect, réémission de chant, et délimitation du territoire) ont été utilisées pour faire des estimations de la densité de la Mésite Variée Mesitornis variegata dans la forêt sèche de l'ouest de Madagascar. L'espèce est considérée comme menacée et appartient à une famille endémique de relations obscures. La population dans la région du Menabe, centre-ouest Madagascar, estimé avec la réémission de chant (la méthode la plus efficace) est entre 3,000-19,000; celle de l'Ankarafantsika, nord-ouest Madagascar, est entre 6,000-26,000. Les autres populations occidentales sont probablement des vestiges. L'habitat où l'espèce se trouve le plus commune est à côté des rivières dans la forêt exploitée, dans la partie méridionale de son aire de distribution, et dans forêt intacte sur sable dans le partie septentrionale. L'espèce paraît etre absente dans d'autres régions, même où l'habitat est similaire. Elle existe rarement ou pas du tout dans les forêts secondaires ou brûlées. Les rongeurs introduits et l'exploitation forestière sélective ne posent pas probablement un grand problème pour l'espèce, mais la chasse et le defrîchement pour l'agriculture sont localement importante.

\section{Introduction}

The western deciduous forests of Madagascar, as with deciduous forests all over the tropics, are subject to many human pressures, including subsistence and commercial exploitation and clearance for pasture or crops (Murphy and Lugo 1986, Janzen 1988). The surface area of western forest has recently been estimated at 1,200,000 ha (Smith et al. 1991), less than half previous estimates (Chauvet 1972, Jenkins 1987). It is not clear if this reduction is due to forest 
destruction or better estimates, but forest clearance undoubtedly occurs. The need for management of these and other Malagasy forest resources is discussed in Nicoll and Langrand (1989).

Many tropical forest birds are affected by alteration of their habitat. Recent work (for example Bell 1982, Johns 1986, 1989, 1991, Howard 1991, Lambert 1992, Thiollay 1992) has demonstrated that some guilds and taxa are more sensitive than others. The susceptibility of some species may be exacerbated by their importance as human food, narrow geographical range, low population density or habitat specificity (Karr 1977, Strahl and Grajal 1991). Species with a combination of these characteristics should particularly be targeted for management, in the name of biodiversity conservation (Kelly and Harwell 1990, Spellerberg 1991, Strahl and Grajal 1991).

Recent work at Kirindy Forest $\left(20^{\circ}{ }^{\circ} 3^{\prime} \mathrm{S} 44^{\circ} 43^{\prime} \mathrm{E}\right.$; Ganzhorn et al. 1989, 1990, Ganzhorn and Sorg in press) has shown that the short-term effects of low-level commercial exploitation on the vertebrate fauna of these forests are limited. Kirindy Forest is managed as a low-intensity logging concession and forestry training centre by the Swiss-backed Centre de Formation Professionelle Forestière (CFPF). The CFPF has exploited around $60 \%$ of the concession, removing on average 5-15 trees or $10 \mathrm{~m}^{3} \mathrm{ha}^{-1}$ (Cuvelier 1990); great care is taken when removing logs not to disturb the forest, and replanting with native species follows exploitation.

One bird species present at Kirindy that has a very limited worldwide distribution and belongs to a feeding guild recognized as susceptible to forest change is the White-breasted Mesite Mesitornis variegata (Hawkins and Wilmé in press). It feeds largely on invertebrates obtained from the litter layer, a food resource known to be altered by forest exploitation (Levings and Windsor 1984, Johns 1986). Other species feeding in this way respond negatively to selective logging (Johns 1986, 1991, Lambert 1992, Thiollay 1992). The White-breasted Mesite occupies territories year-round and appears to live in family groups (Appert 1985, Langrand 1990, Hawkins 1993). Nests with eggs, adults ready to lay or downy young have been found in OctoberFebruary, April and May (Lavauden 1931, Rand 1936, Langrand 1990, R.J. Safford verbally 1992, A.F.A.H. unpublished data). It is a member of an endemic family (Mesitornithidae) of obscure taxonomic affinities (Sibley and Ahlquist 1990), was listed as a threatened species under the category "Rare" in the international bird Red Data Book (Collar and Stuart 1985), and has recently been reclassified as "Vulnerable" (Collar et al. 1994). In western forests the White-breasted Mesite is known from four areas (Langrand 1990) representing three disjunct forest blocks, in northern Madagascar, Ankarafantsika and Menabe (Figure 1). Most unexpectedly, it or a very similar form has recently been discovered at Ambatovaky, an eastern rainforest site (Thompson and Evans 1992).

The goals of the present study were to search for White-breasted Mesites in areas outside their known range; to evaluate three different survey techniques for measuring density; to estimate density where the species occurred; and to assess local people's knowledge of the species, particularly in relation to hunting. From these the conservation status of the White-breasted Mesite could be assessed. 


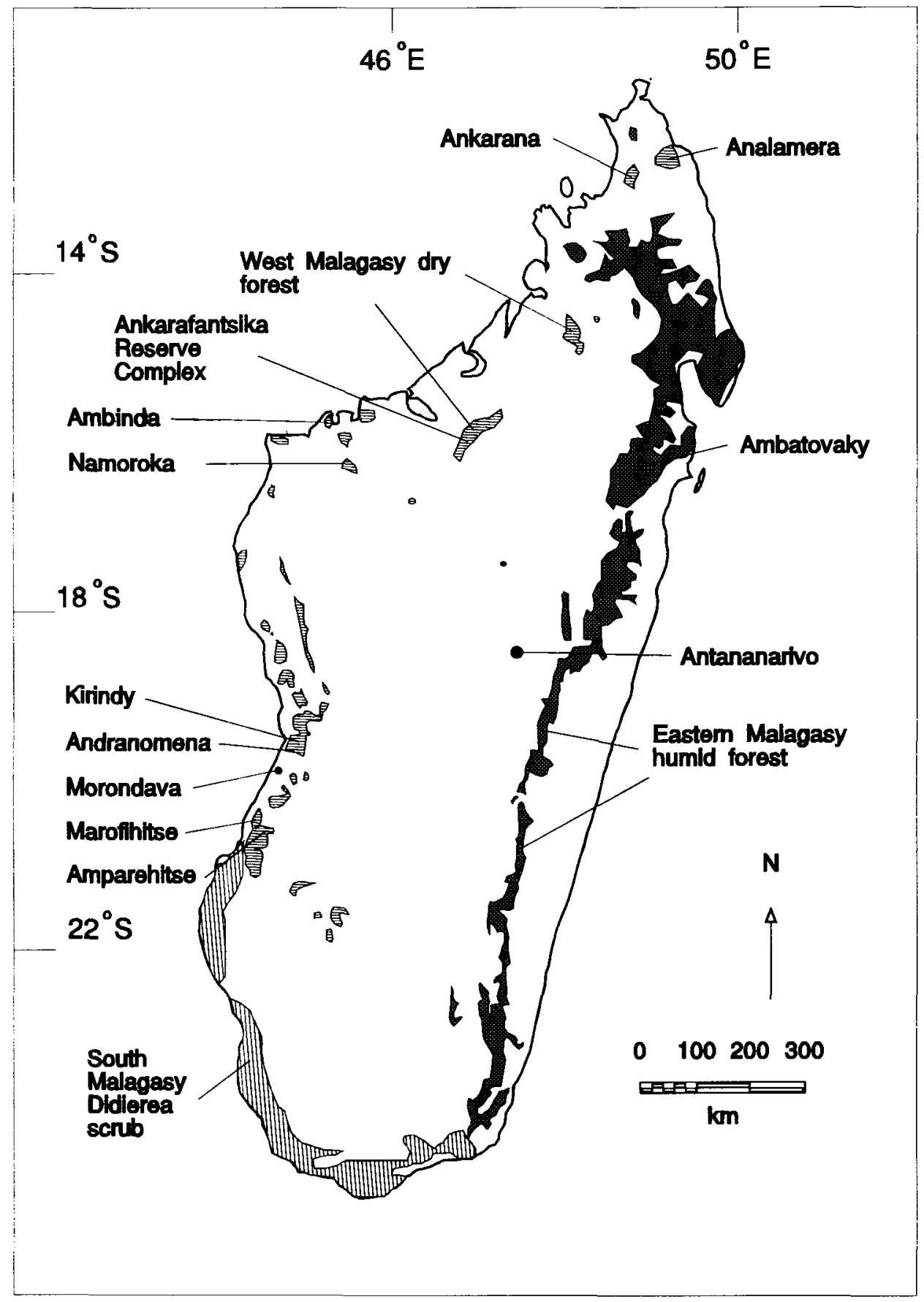

Figure 1. Madagascar showing sites mentioned in the text, and current estimates of forest cover for the three main Malagasy forest types. 


\section{Methods}

Searches or density estimates were made for White-breasted Mesites at (from north-east to south-west): Ampijoroa Forestry Station $\left(16^{\circ} 20^{\prime} \mathrm{S} 46^{\circ} 45^{\prime} \mathrm{E}\right)$, part of the Ankarafantsika Reserve complex; Ambinda forest near Soalala ( $16^{\circ} \mathrm{Oo}$ 'S $\left.45^{\circ} 14^{\prime} \mathrm{E}\right)$; Namoroka Strict Nature Reserve $\left(16^{\circ} 28^{\prime} \mathrm{S} 45^{\circ} 20^{\prime} \mathrm{E}\right)$; in the Menabe area at Kirindy Forest concession $\left(20^{\circ} 03^{\prime} \mathrm{S} 44^{\circ} 43^{\prime} \mathrm{E}\right)$ and at Andranomena Special Reserve $\left(20^{\circ} 10^{\prime} \mathrm{S} 44^{\circ} 30^{\prime} \mathrm{E}\right.$ ); south of Morondava at Marofihitse (or Marofihitra) Forest $\left(20^{\circ} 47^{\prime} \mathrm{S} 44^{\circ} \mathrm{Or}\right.$ ' E) and Amparehitse (or Amparehitre) Forest $\left(20^{\circ} 5^{\prime} \mathrm{S} 44^{\circ} \mathrm{O} 6^{\prime} \mathrm{E}\right)$. Mesites had already been recorded at Ampijoroa Forestry Station and Ankarafantsika Reserve (Lavauden 1931, Nicoll and Langrand 1989, Langrand 1990) and, in Menabe, at Kirindy Forest concession (Langrand 1990) and Andranomena (Appert 1985). In addition, the species is known from Ankarana Special Reserve (12 $50^{\circ} \mathrm{S} 48^{\circ} 55^{\prime} \mathrm{E}$ ) (Rand 1936), where an estimate of population size (100-250 birds) has already been made (Hawkins et al. 1990), and from the nearby Analamera Special Reserve (Nicoll and Langrand 1989). All localities are shown in Figure 1, with those in the Menabe region in Figure 2.

Biogeographically speaking, the Western Domain forests of the Western Region (Nicoll and Langrand 1989), shown on Figure 1, might be expected to support White-breasted Mesites (Lavauden 1937, Milon et al. 1973, Appert 1985, Langrand 1990), but no systematic searches have been made for the species. There is some regional variation in the structure and composition of the forest in line with a rainfall gradient increasing to the north. Forests around Marofihitse in the south have many xerophytic tree species and are mostly deciduous, while forests at Ampijoroa in the north-west are much less xerophytic and generally more evergreen. A more profound source of structural variation and species composition is associated with local changes in substrate and water availability. A more detailed review of the ecology and composition of these forests can be found in Jenkins (1987), Nicoll and Langrand (1989) and CFPF (1991).

A survey and density measurement methodology was developed at Ampijoroa and Kirindy, where the species was already known to occur. Three complementary techniques were used: visual detection on fixed-length transects, auditory surveys using call playback, and territory mapping. Searches for mesites in sites where they had not previously been recorded were made by a combination of cold searching in likely sites, call-playback, and interviews with local people.

July and August 1991 were spent in Kirindy Forest searching for mesites and assessing mesite foraging site preference (Hawkins in press). Ten days were spent at the end of this period searching for mesites in the nearby Andranomena Special Reserve and the adjoining Ampataka Classified Forest, $15-25 \mathrm{~km}$ southwest of Kirindy (Figure 2).

Repeat surveys were made in Kirindy in March, July and September 1993, and at Andranomena in December 1992. The periods September-October 1991, December 1991-January 1992, January, April-May and August 1993 were spent at Ampijoroa. Marofihitse and Amparehitse were visited in November 1992, Ambinda in February 1993, and Namoroka in October 1993. 


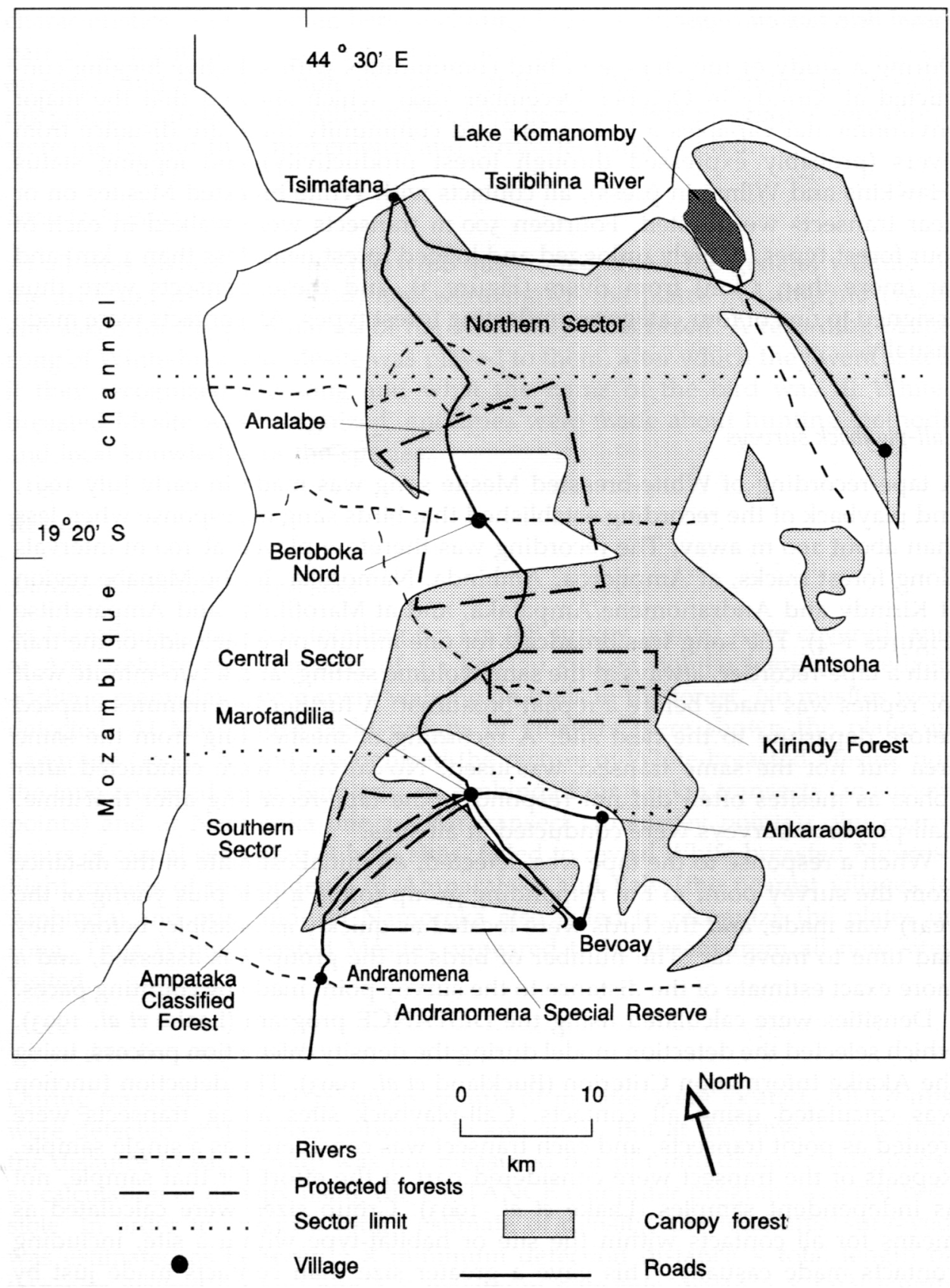

Figure 2. Menabe region showing protected forests, study sites and extent of forest cover (based on Ducenne et al. 1988). 


\section{Visual detection on transects}

During a study of the change in bird communities with selective logging conducted at Kirindy in October-December 1990, which showed that the major environmental variables affecting the bird community there are distance from rivers (probably expressed through forest productivity) and logging status (Hawkins and Wilmé in press), all contacts with White-breasted Mesites on or near transects were noted. Fourteen $500 \mathrm{~m}$ transects were walked in each of four forest types, namely unlogged and logged forest near (less than $1 \mathrm{~km}$ ) and far (more than $1 \mathrm{~km}$ ) from rivers (Figure 3), and these transects were thus assigned to one of four categories reflecting forest types. All contacts were made casually.

\section{Call-playback surveys}

A tape-recording of White-breasted Mesite song was made in early July 1991, and playback of the recording established that birds sang in response when less than about $100 \mathrm{~m}$ away. The recording was therefore played at $100 \mathrm{~m}$ intervals along forest tracks, at Ampijoroa, Ambinda, Namoroka, in the Menabe region at Kirindy and Andranomena/Ampataka, and at Marofihitse and Amparehitse (Figures 1-4). The song was broadcast for one minute on either side of the trail with a tape-recorder, always at the same volume setting, and a two-minute wait for replies was made before a repeat broadcast. A further two minutes elapsed before departure to the next site. A recording of mesite song from the same area but not the same transect was used. No surveys were conducted after Iohoo as mesites often did not respond to the tape-recording after that time. Call-playback surveys were conducted at all sites.

When a response to the tape was detected, an initial estimate of the distance from the survey point to the responding group (often a pair plus young of the year) was made, and the birds were located as quickly as possible, before they had time to move far. The number of birds in the group was assessed, and a more exact estimate of the distance to the survey point made by counting paces.

Densities were calculated using the DISTANCE program (Laake et al. 1993), which selected the detection model during the density calculation process, using the Akaike Information Criterion (Buckland et al. 1993). The detection function was calculated using all contacts. Call-playback sites along transects were treated as point transects, and each transect was considered as a single sample. Repeats of the transect were considered part of the effort for that sample, not as independent samples (Laake et al. 1993). Group sizes were calculated as means for all contacts within the site or habitat-type within a site, including contacts made casually. This gave a greater size than contacts made just by using call-playback.

\section{Territory mapping}

In Jardin Botanique " $\mathrm{A}$ " (hereafter JBA: a 26 ha block of forest with a trail network - see Figures 5 and 6) at Ampijoroa during September 1991-January 1992, mesite groups were located using call-playback and notes made of the 
characteristics of group members, including breast markings, feather and barepart abnormalities and general coloration. Contacts with groups were marked on maps, and particular note was made of the locations of simultaneously singing groups. Groups were followed for long periods while foraging observations were made, and their movements and territorial battles noted.

\section{Local knowledge}

At all sites visited, local people were questioned about the general wildlife of the area and its use for food, and were shown the plates in Langrand (1990) and asked for the local names of the birds they recognized. A recording of the song of White-breasted Mesite was played to them, after which they were asked if they recognized the song and what the name of the bird was. If Whitebreasted Mesite was recognized, enquiries were made about hunting methods and local knowledge of the species.

\section{Results}

Searches for mesites in new sites

At Marofihitse, transects totalling $6.7 \mathrm{~km}$ (68 survey points) were covered, and at Amparehitse two transects of $1.1 \mathrm{~km}$ (20 survey points) were covered; in addition many days were spent walking on trails in the forest. No mesites were detected. At Marofihitse eight groups of villagers were shown the plates in Langrand (1990). Nobody recognized the picture of White-breasted Mesite, nor the tape-recorded song. Similarly, at Ambinda four $1.1 \mathrm{~km}$ transects (4o survey points) and at Namoroka one $1.1 \mathrm{~km}$ transect (10 survey points), plus many hours of casual searching at both sites, failed to reveal White-breasted Mesites. Eight groups of respondents in Amparafaka and Baly (the nearest villages to Ambinda) and our guide in Namoroka also failed to recognize the plates or song. Thus White-breasted Mesites appeared to be absent from all new sites visited.

\section{Visual detection on transects}

During transects (Figure 3), seven groups of mesites were located. All groups were detected at distances between 10 and $20 \mathrm{~m}$, but at the time of detection the distance to each group was not measured nor put into distance categories, so calculation of density using the DISTANCE computer program was not possible. In order to obtain a rough estimate of density, the total area surveyed was estimated as between $2 \times$ minimum detection distance $\times$ total length of transects walked $(31 \mathrm{~km})$ and $2 \times$ maximum detection distance $\times$ total length of transects walked (Table 1 ).

\section{Call-playback}

At Kirindy, density was calculated for each forest type (logged/unlogged, near/ far from rivers) (Table 2). Figure 4 shows the area searched using call-playback and the locations of mesite groups. 


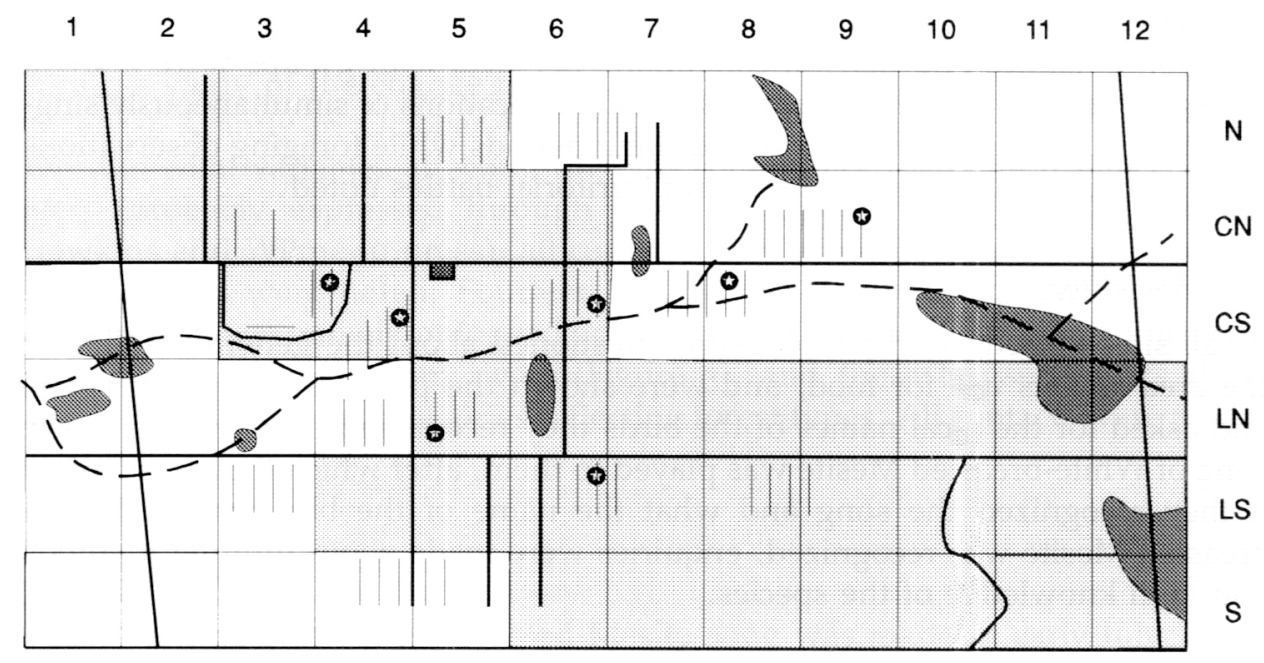

Logged parcels Logging trails Savanna $\$ Mesite sightings

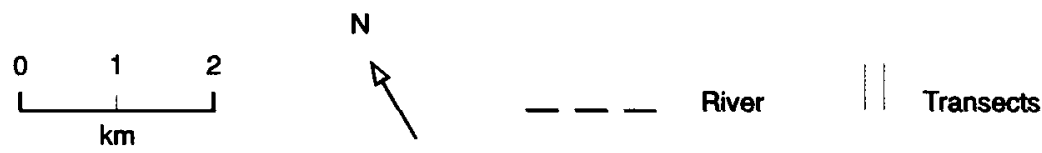

Figure 3. Kirindy Forest showing logged parcels, transect sites and mesite groups seen on transects only. The grid is used to divide the forest into parcels for exploitation but is not marked on the ground. Apart from the savanna patches marked, the whole area is forested.

Sample size in unlogged forest far from rivers was small compared with surface area. Most of the forest in this category was more than an hour's walk from camp. Group size is significantly smaller in logged forest far from rivers than in logged forest close to rivers (two-tailed $t$-test, $T_{47}=2.04, P<0.05$ ), whereas group size does not differ significantly between logged and unlogged forest (two-tailed $t$-test, $\mathrm{T}_{7}=0.57, \mathrm{P}>0.1$ ).

In Andranomena and Ampataka (Figure 2), 148 survey points were sampled with a total effort of 205 . Only three mesite groups were located. The density estimate is 1.3 (95\% confidence intervals $0.10-3.17$ ) groups $\mathrm{km}^{-1}$.

At Ampijoroa, surveys were carried out for mesites in a wider range of habitat types than were accessible in the Menabe region (Figure 5, Table 3). Histories of survey areas were obtained from M. Rabemazava, the Chief Warden. Primary sand forest including JBA (column 1, Table 3) has never been burnt and is little exploited. It is similar in structure and composition to forest at Kirindy but the canopy is lower and lacks baobabs Adansonia spp. (Nicoll and Langrand 1989). Secondary sand forest (column 2) has been burnt at least once in the last 10 years and is very disturbed. Canopy cover is less than $30 \%$ and there is very dense shrubby vegetation to a level of around $2 \mathrm{~m}$. Valley forest (column 3 ) is 

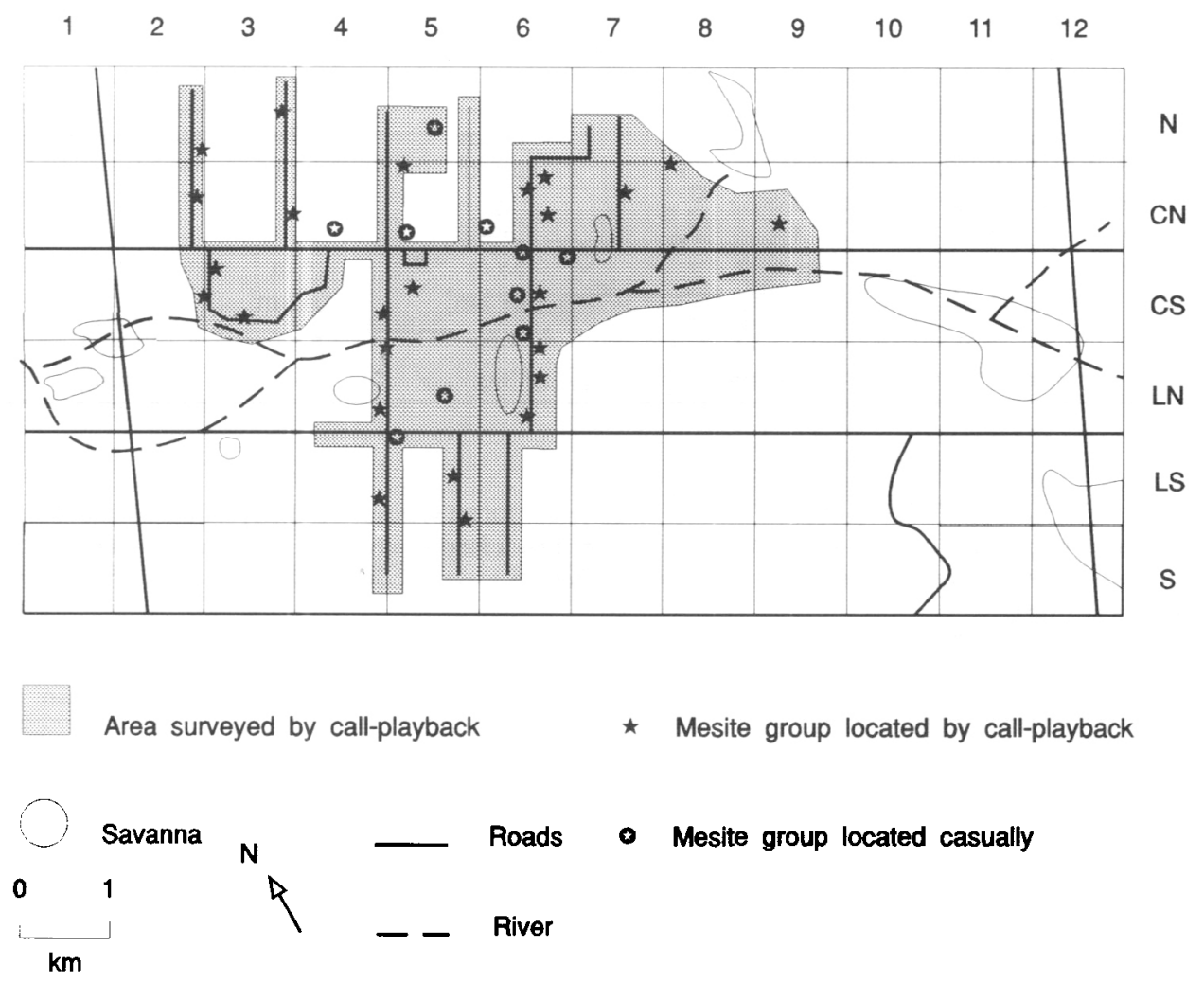

Figure 4. Kirindy Forest showing the area surveyed using call-playback, and the location of mesite groups found casually and by call-playback.

mostly disturbed, by exploitation for structural timber and cultivation. Some areas are completely secondary. Most trees are less than $20 \mathrm{~m}$ in height, and there is a dense shrub layer. Some areas were marshy raffia-palm swamp as little as 15 years ago. Cattle are present in or pass through most areas of valley forest, and in small areas trampling or browsing damage is heavy. In some areas the canopy is dominated by tamarind Tamarindus indica and mango Mangifera indica; in such places the shrub layer is reduced and the understorey open.

Group size was significantly smaller in degraded sand forest than in either undisturbed sand forest or valley forest ( $\mathrm{t}$-tests; $\mathrm{T}_{19}=3.12, \mathrm{P}=0.0057, \mathrm{~T}_{25}=$ $3.58, P=0.0014$ respectively). Group size was not significantly different between undisturbed sand forest and valley forest $\left(\mathrm{T}_{30}=1.41, \mathrm{P}<0.1\right)$.

\section{Territory mapping}

All mesite territories in a survey grid of 26 ha in JBA were mapped (Figure 6). Groups were located using call-playback and then followed, for a total of 186 hours, between September 1991 and January 1992.

Five groups had territories centred within the survey grid (Figure 6, Table 4), and another seven had territories that overlapped it. The sum of the parts of 
Table 1. Three density estimates for White-breasted Mesites using different detection distances based on visual detection on $500 \mathrm{~m}$ transects. Sixty-two transects were walked; 14 in each of four forest types (logged/unlogged near/far from rivers) of which six were walked twice.

Total distance walked on transects

Forested area of concession

Number of encounters with species

Mean group size

Estimated $100 \%$ detection distance

Total area surveyed

Group density estimate per $\mathbf{k m}^{2}$

Total population estimate in concession

\begin{tabular}{ccc}
$31 \mathrm{~km}$ & $31 \mathrm{~km}$ & $31 \mathrm{~km}$ \\
$62 \mathrm{~km}^{2}$ & $62 \mathrm{~km}^{2}$ & $62 \mathrm{~km}^{2}$ \\
7 & 7 & 7 \\
2.3 & 2.3 & 2.3 \\
$20 \mathrm{~m}$ & $15 \mathrm{~m}$ & $10 \mathrm{~m}$ \\
$1.24 \mathrm{~km}^{2}$ & $0.93 \mathrm{~km}^{2}$ & $0.62 \mathrm{~km}^{2}$ \\
5.64 & 7.52 & 11.2 \\
804 & 1,072 & 1.597 \\
\hline
\end{tabular}

Table 2. Densities of White-breasted Mesites in different forest types at Kirindy. Of the total concession area of $70 \mathrm{~km}^{2}$, only $66 \mathrm{~km}^{2}$ was mapped. Of this, $4 \mathrm{~km}^{2}$ is savanna, and thus unsuitable for mesites. Forest types are discussed in the text. Densities were calculated using DISTANCE. For details see text.

\begin{tabular}{|c|c|c|c|c|c|}
\hline & $\begin{array}{c}\text { Unlogged } / \\
\text { near }\end{array}$ & Unlogged/far & Logged/near & Logged/far & $\begin{array}{l}\text { Total or } \\
\text { mean }\end{array}$ \\
\hline Survey points & 47 & 23 & 64 & 107 & 241 \\
\hline $\begin{array}{l}\text { Total survey effort (includes } \\
\text { repeats) }\end{array}$ & 90 & 23 & 140 & 179 & 432 \\
\hline Mesite groups responding & $\mathbf{1}$ & 2 & 17 & 16 & 36 \\
\hline Mean group size $( \pm S D)$ & $\begin{array}{l}3.0 \\
(0.0)\end{array}$ & $\begin{array}{c}2.5 \\
(0.58)\end{array}$ & $\begin{array}{c}2.73 \\
(0.73)\end{array}$ & $\begin{array}{c}2.26 \\
(0.56)\end{array}$ & \\
\hline $\begin{array}{l}\left.\text { Density (groups } / \mathrm{km}^{2}\right)(95 \% \\
\text { conf. int.) }\end{array}$ & $\mathrm{N} / \mathrm{C}$ & $\begin{array}{c}5.18 \\
(1.42-18.90)\end{array}$ & $\begin{array}{c}8.84 \\
(5.17-14.44)\end{array}$ & $\begin{array}{c}5.13 \\
\left(2.55^{-10.32)}\right.\end{array}$ & \\
\hline $\begin{array}{l}\text { Estimated surface area in } \\
\text { concession }\left(\mathrm{km}^{2}\right)\end{array}$ & 8 & 15 & 7 & 32 & 62 \\
\hline $\begin{array}{l}\text { Estimate of mesite } \\
\text { population } \\
\text { (density } \times \text { mean group } \\
\text { size } \times \text { surface area }(95 \% \\
\text { conf. int.) }\end{array}$ & $\mathrm{N} / \mathrm{C}$ & $53-708$ & $99-276$ & $184-746$ & $336-1,730$ \\
\hline $\begin{array}{l}\text { Estimate of individuals in } \\
\text { breeding population ( } 2 \\
\text { adults per group) ( } 95 \% \\
\text { conf. int.) }\end{array}$ & $\mathrm{N} / \mathrm{C}$ & $(43-567)$ & $(72-202)$ & $(163-660)$ & $\left(27^{8}-1,429\right)$ \\
\hline
\end{tabular}

$\mathrm{N} / \mathrm{C}$, not calculated owing to very low response rate.

group territories within the 26 ha of JBA is 5.3 (Table 4). Call-playback density estimates for primary sand forest (Table 3 ) predict 3.77 (95\% confidence intervals 2.9-5.0) groups of mesites in 26 ha of forest.

Sample sizes were inadequate to assess the relationship between group size and territory size; there appears to be no obvious trend (Table 4, Figure 6).

\section{Local knowledge}

All four independent groups of respondents at Marofandilia, adjacent to Andranomena, recognized the picture of White-breasted Mesite as "Agolin'ala" 


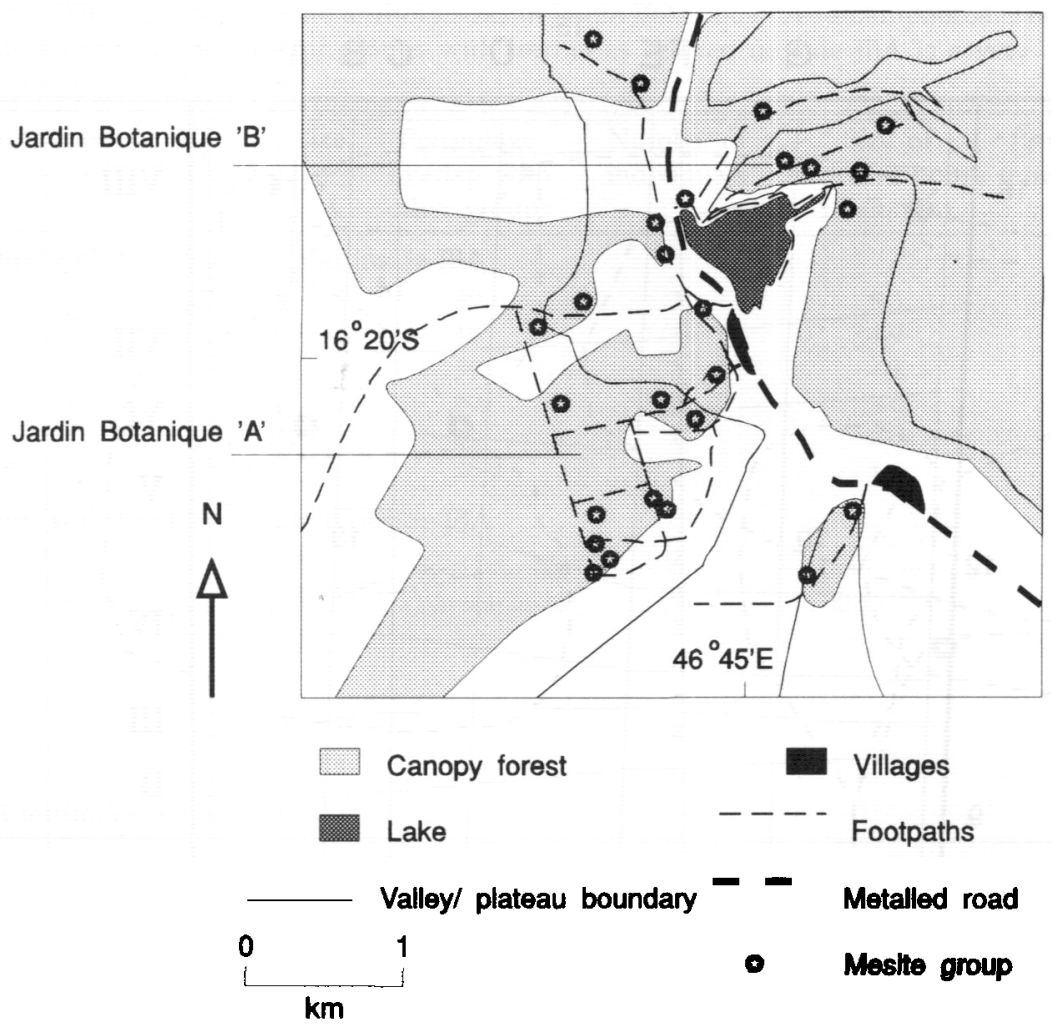

Figure 5. Ampijoroa Forestry Station showing study areas and mesite groups located outside Jardin Botanique "A" (partly from DEF/UNDP/UNESCO undated).

Table 3. Densities of White-breasted Mesites in different forest types at Ampijoroa, calculated using DISTANCE (Laake et al. 1993). Vegetation types are discussed in the text.

Primary sand Degraded sand Valley forest Total or mean forest (includes forest

JBA)

\begin{tabular}{|c|c|c|c|c|}
\hline Survey points & 52 & 31 & 59 & 142 \\
\hline $\begin{array}{l}\text { Total survey effort (includes } \\
\text { repeats }\end{array}$ & 300 & 46 & 68 & 414 \\
\hline Mesite groups responding & 26 & 7 & 17 & 50 \\
\hline $\begin{array}{l}\text { Density estimate: (groups } / \mathrm{km}^{2} \text { ) } \\
\text { ( } 95 \% \text { conf. int.) }\end{array}$ & $\begin{array}{c}14.5 \\
(11.2-19.2)\end{array}$ & $\begin{array}{c}3.5 \\
(1.2-10.4)\end{array}$ & $\begin{array}{c}6.8 \\
(2.6-17.6)\end{array}$ & 8.27 \\
\hline Mean group size ( \pm SD) & 2.4 & 1.9 & 2.7 & 2.3 \\
\hline
\end{tabular}

JBA, Jardin Botanique "A".

(Agoly $=$ White-throated Rail Dryolimnas cuvieri, ala = forest), and all used the same name when they heard the recorded song. They said that this bird was good to eat, and easy to hunt as it often froze when approached. Three methods of hunting were described: noose traps in the forest (usually set to catch couas 


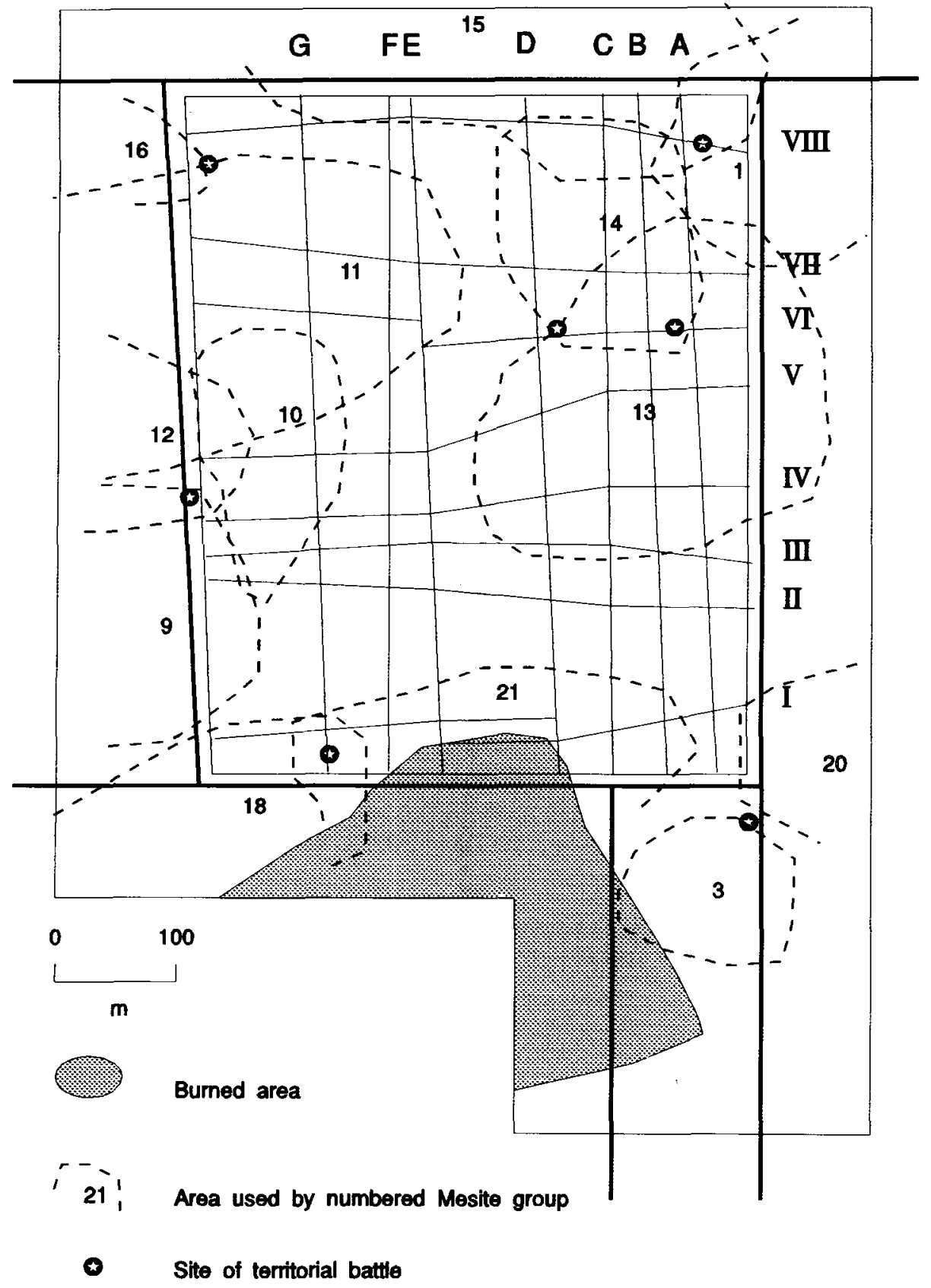

\section{Wide paths}

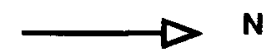

Narrow paths: VIII, G etc. are path labels

Figure 6. Jardin Botanique " $\mathrm{A}$ " showing mesite territories and sites of group territorial disputes. Territory boundaries are convex polygons drawn around initial call-playback contact sites. 
Table 4. White-breasted Mesite territory sizes in Jardin Botanique "A" at Ampijoroa. The proportion of the territory inside JBA of groups with territories centred outside JBA is a very approximate estimate only.

\begin{tabular}{cccccc}
\hline Group number & $\begin{array}{c}\text { Territory size } \\
\text { (ha) }\end{array}$ & $\begin{array}{c}\text { Percentage } \\
\text { overlap with } \\
\text { other groups }\end{array}$ & $\begin{array}{c}\text { Number of } \\
\text { individuals }\end{array}$ & $\begin{array}{c}\text { Size of } \\
\text { exclusive home } \\
\text { range (ha) }\end{array}$ & $\begin{array}{c}\text { Proportion of } \\
\text { JBA within }\end{array}$ \\
\hline
\end{tabular}

Groups with territories centred inside JBA

$\begin{array}{llllll}11 & 6.6 & 20 & 3 & 5.3 & 0.6 \\ 13 & 6.0 & 19 & 3 & 4.9 & 0.8 \\ 14 & 4.0 & 39 & 3 & 2.4 & 1 \\ 21 & 3.8 & 20 & 2 & 3.0 & 0.6 \\ 10 & 1.4 & 43 & 2 & 0.8 & 1 \\ \text { Mean } & 4.4 & 28.2 & & 3.3 & \end{array}$

Groups with territories centred ouside JBA

\begin{tabular}{lll}
16 & 2 & 0.1 \\
15 & 2 & 0.1 \\
12 & 2 & 0.3 \\
9 & 2 & 0.2 \\
18 & 2 & 0.2 \\
20 & 2 & 0.1 \\
1 & 2 & 0.3 \\
Total territories within JBA & & 5.3 \\
\hline
\end{tabular}

Couinae or Madagascar Crested Ibis Lophotibis cristata), killing with a catapult or slingshot, or chasing the bird until exhausted. However, the interviewees also said the bird was not specifically targeted as it was small and not all that common.

The forest guard at Kirindy knew White-breasted Mesites well and hunted them by flushing them into trees with dogs, where they could be killed with a catapult. During my stay at Kirindy he killed mesites at least twice. During the cold dry season, when tenrecs Tenrec ecaudatus, a popular wet-season food source, hibernate, protein may be difficult to obtain and even relatively small birds like mesites are targeted, particularly if they are easy to catch.

At Ampijoroa, people were unwilling to discuss hunting birds as I was associated with the reserve warden and they did not wish to implicate themselves in poaching. However, one hunter, when shown a pair of White-breasted Mesites, said that the species was casually hunted but not targeted as it was too small; preferred species included couas and Madagascar Crested lbis. Mesites were shot from perches with catapults after they had been flushed by dogs, or the females were removed from nests, but the eggs were not taken.

\section{Regional population estimates}

Much of the forest surrounding the two major study sites was not visited, so the presence of White-breasted Mesites could not be confirmed except where noted below, and even the relative extent of different forest types is unknown. Regional populations were therefore calculated as probable ranges rather than central estimates. The criteria used to define the range are given in each case. 
Table 5. Estimates of population of White-breasted Mesites in the Menabe region. Density estimates used to calculate ranges are the highest and lowest density estimates calculated for samples within the region. Mean group size for the whole area is 2.55. Areas of forest blocks are my estimations from Ducenne et al. (1988). Sector boundaries are shown on Figure 2. Population estimates are rounded to the nearest 10 .

\begin{tabular}{lccc}
\hline Area $\left(\mathrm{km}^{2}\right)$ & $\begin{array}{c}\text { Range of densities } \\
\left(\mathrm{groups} / \mathrm{km}^{2}\right)\end{array}$ & Population range & $\begin{array}{c}\text { Range of breeding } \\
\text { adults }\end{array}$ \\
\hline Southern sector $(\mathbf{1 4 7})$ & $0.1-3.17$ & $40-1,190$ & $30-930$ \\
Central sector $(516)$ & $1.3-8.8$ & $1,710-11,580$ & $1,340-9,080$ \\
Northern sector $(288)$ & $1.3-8.8$ & $960-6,470$ & $750-5,070$ \\
Total $(951)$ & & $2,710-19,240$ & $2,120-15,080$ \\
\hline
\end{tabular}

Table 5 shows population estimates for the White-breasted Mesite in sectors of the Menabe region. Sector boundaries are shown in Figure 2. Mean group size was calculated from all contacts, casual and on transects, in Andranomena and Kirindy. I did not record White-breasted Mesites in the northern sector during brief visits in 1990, but Appert (1985) saw a group of four, $15 \mathrm{~km}$ northnorth-west of Beroboka (Figure 2) in 1974, confirming that the species does occur in this sector.

Much of the southern half of Andranomena reserve, plus the west of Ampataka and the area of forest to the east of Bevoay, is very degraded, with areas of forest burnt for cultivation, and extensive and illegal commercial timber exploitation (Figure 2). They are thus unlikely to support any substantial mesite populations, and degraded parts of these designated forests are not included in canopy forest surface area estimates in Table 5. Appert (1985) recorded the species about $10 \mathrm{~km}$ south-west of Marofandilia in 1974, but failed to find it in forests around that village, presumably in the area I was working.

The regional population range estimates are calculated as if the maximum and minimum densities in different parts of Kirindy applied over the whole of the northern and central regions. In the southern sector, where hunting is likely to be heavy as a result of higher human population density, I have used the maximum and minimum estimates from Andranomena, where it seems that hunting has reduced density in otherwise suitable habitat.

Ampijoroa Forestry Station is part of the reserve complex of Ankarafantsika, which covers a total of 135,000 ha (Ramaromanga 1993). The Strict Reserve of Ankarafantsika covers 65,000 ha, of which about 43,500 ha is undisturbed sand forest or gallery forest in river valleys (my estimates from DEF/UNDP/UNESCO undated; Figure 7). According to Ramaromanga (1993), Ampijoroa Forestry Station covers 20,00o ha and the Forestry Reserve of Ankarafantsika covers a further 50,00o ha. Maps produced by DEF/UNDP/UNESCO (undated) do not identify Ampijoroa Forestry Station, but show a total surface area for Ankarafantsika Forest Reserve of 68,000 ha, of which 35,300 ha is canopy forest (51.7\%; my measurements). I assume this includes Ampijoroa Forestry Station. Table 6 shows a range of population estimates based on these surface area estimates, calculated using the maximum and minimum densities observed at Ampijoroa Forestry Station. 

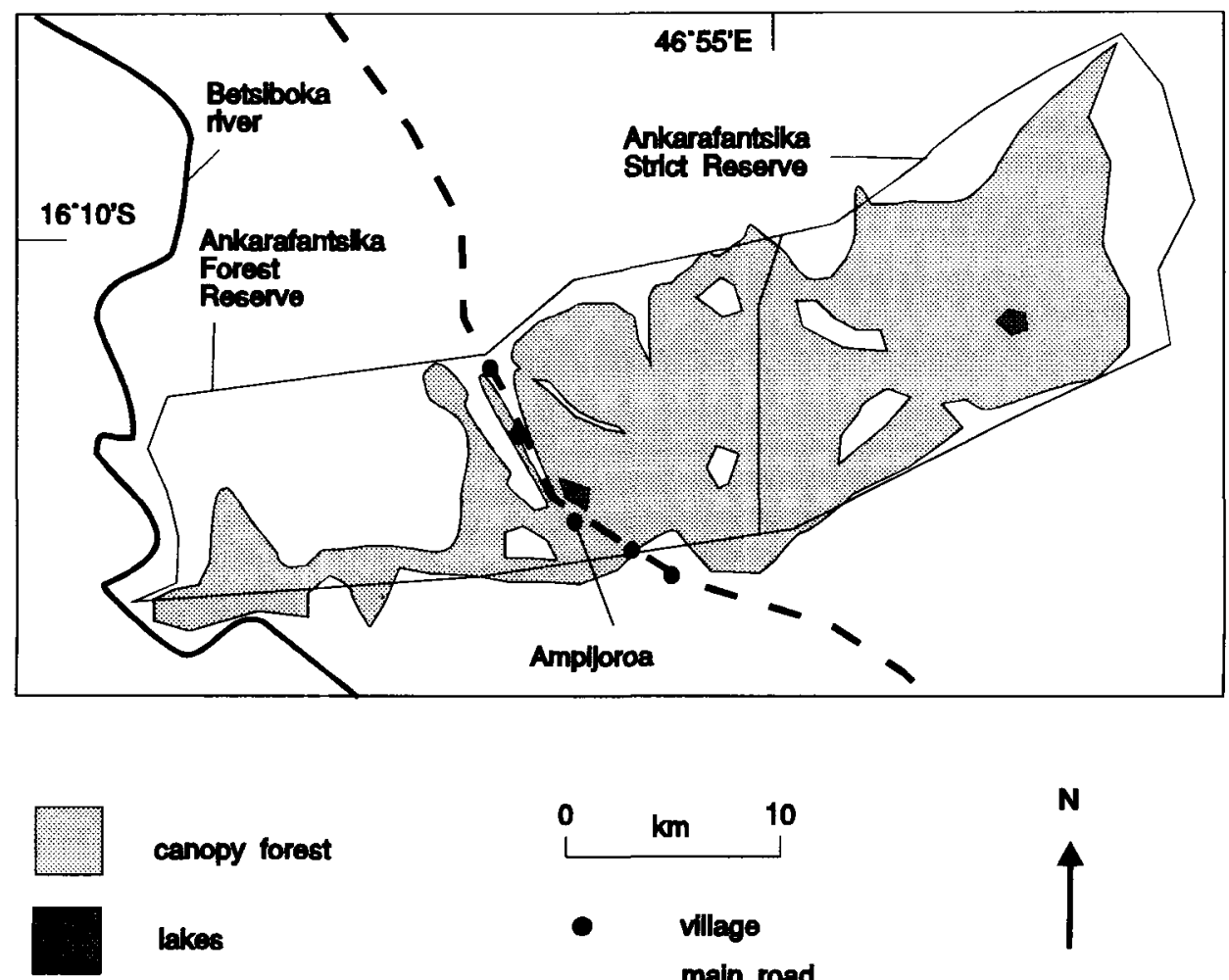

canopy forest

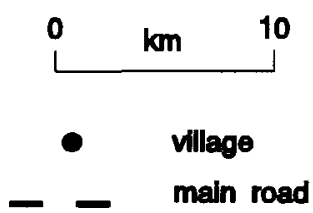

$\mathbf{N}$

lakes

main road

Figure 7. Ankarafantsika Reserve complex showing forest cover and location of Ampijoroa Forestry Station (from DEF/UNDP/UNESCO undated).

Table 6. Population estimates for parts of Ankarafantsika Reserve complex. Mean group size for all areas is 2.3. Ranges of population estimates are calculated using the highest and lowest density estimates for samples made in the region. Areas are my calculations from DEF/UNDP/UNESCO (undated). Forest blocks are shown on Figure 7. Population estimates are rounded to nearest 10.

\begin{tabular}{lccc}
\hline Area $\left(\mathrm{km}^{2}\right.$ ) & $\begin{array}{c}\text { Group density range } \\
\text { (groups/km })\end{array}$ & Range of population & $\begin{array}{c}\text { Range of breeding } \\
\text { adults }\end{array}$ \\
\hline $\begin{array}{l}\text { Ankarafantsika Strict Nature } \\
\text { Reserve (435) }\end{array}$ & $3 \cdot 5-14.5$ & $3,500-14,510$ & $3,050-12,610$ \\
$\begin{array}{l}\text { Ankarafantsika Forestry } \\
\text { Reserve (353) }\end{array}$ & $3 \cdot 5-14.5$ & $2,840-11,770$ & $2,470-10,240$ \\
Total & & $6,340-26,280$ & $5,520-22,850$ \\
\hline
\end{tabular}

\section{Other populations}

The population in Ankarana (Figure 1 ) was estimated at between 100 and 250 in 1987 (Hawkins et al. 1990). The species is also known from Analamera (c. $12^{\circ} 15^{\prime} \mathrm{S}$ $49^{\circ} 27^{\prime} \mathrm{E}$ : Figure 1), and in the east at Ambatovaky (c. $16^{\circ} 45^{\prime} \mathrm{S} 49^{\circ} 15^{\prime} \mathrm{E}$ : Thompson and Evans 1992), but in both these cases the population levels are entirely unknown. 


\section{Discussion}

\section{Comparison of survey methods}

Population estimates of White-breasted Mesites derived from unprompted encounters (sightings or song) produced very low sample sizes for the amount of effort involved. This is due to the low detectability of mesites, which sing rather irregularly, often only once or twice in a morning. In addition, visual detectability of mesites varies greatly with vegetation type, as it does with other species (Bibby and Buckland 1987); in some dense areas visual detection of mesites was improbable at greater than $5 \mathrm{~m}$. The population range produced by this method for Kirindy (804-1,597; Table 1 ) is $110-200 \%$ of that produced by call-playback. This discrepancy is difficult to account for. Estimates of density made by visual detection on transects are very dependent on the number of contacts made, particularly when the total is small. For better density estimates, more samples and accurate measurement of distance of the birds from the transect line are required. If a lot of time is spent conducting transect surveys for other species, then casual encounters with mesites might provide useful data. However, this method does not seem an efficient way of estimating mesite densities. To quote Appert (1985), "I would wander around these forests [in the Menabe area] for days without seeing or hearing a single Mesitornis variegata".

By contrast call-playback is a quick and efficient method of finding Whitebreasted Mesite groups. Over the whole survey period, from a total of 818 survey points (including repeats), 128 mesite contacts representing 89 groups were found or refound by this method. Mean overall encounter rate was one response every 6.39 playback attempts. It was often possible to cover 20 survey points in one morning.

Even with this high encounter rate, there is great variation in density estimates (Tables 2 and 3). Variation in response to call-playback might be expected with season, which might in part account for this. Relatively little surveying was conducted at Kirindy in the early part of the breeding season. However, the range of breeding dates for White-breasted Mesites covers October-May (Langrand 1990), and spontaneous song occurred at all sites throughout the year. Repeat surveys in JBA in the non-breeding season of 1993 indicated that responses may be somewhat less frequent during this season, but differences were not dramatic. A more likely reason for the variation in density estimates seems to be that density varies with habitat.

The calculation of density estimates using call-playback data depends on the following assumptions (Buckland et al. 1993): (a) mesites always respond to the tape when less than $10 \mathrm{~m}$ from the playback point; (b) a response was always made before the birds approached the survey point; (c) birds did not move between responding and being located by the observer; (d) groups consisted of an adult pair plus that year's offspring. However, there is reason to believe that these are sometimes invalid. In particular, mesites were occasionally detected visually next to the survey point after call-playback. This means that the mesites either had not responded to the tape when within $10 \mathrm{~m}$ of the survey point (which breaks assumption [a] and would lead to an underestimation of density) or had moved some distance in response to the call-playback (which violates 
assumption [b], and would lead to an overestimate). The significance of these violations is difficult to judge. If birds were moving significantly before responding, one would expect responses to the second broadcast to be closer than the first. This does not appear to be the case (t-test; $\mathrm{T}_{14}=0.25, \mathrm{P}<0.1$ ), although the sample size is small. Marion et al. (1981) noted that call-playback may lure singing birds into areas that they would not otherwise occupy, so whether estimates of territory size produced using call-playback are realistic is questionable. Figure 6 and Table 4 show that the total of fractions of mesite territories within the 26 ha JBA is about 5.3, slightly higher than the upper confidence interval of the estimate for this area produced by call-playback (Table 3). However, more contacts with the groups in the area of JBA would undoubtedly increase the size of their territories, thereby reducing the proportion of some territories within JBA and making the population estimate more consistent with that produced by call-playback.

General trends indicated by casual encounter rate (for instance, density in different habitats) matched those shown by call-playback surveys, so in relative terms the call-playback technique seems an excellent way of comparing densities within two adjacent areas, where violation of survey assumptions, and the influence of confounding factors such as season, are not so important. The validity of absolute density estimates is more difficult to assess, and larger-scale comparisons with territory-mapping are probably necessary.

Territory-mapping as a method of mesite census is, however, very labourintensive. Most of the period November 1991-January 1992 was spent assessing mesite territories and gathering foraging data on mesites in JBA. It is very time-consuming either to try to trap all the individuals in an area or to get close enough to individuals to identify them by plumage variation. White-breasted Mesites are very reluctant to fly, very easily stressed and quickly become wary of people once trapping is attempted, making further observation difficult. Plumage differences can be used to separate individuals, but this requires long periods of close observation. A better method may be call distinction; some males had idiosyncrasies of song that were useful in differentiating groups. However, assessment of the constancy of these distinctions would be required, and this technique would not provide information about group-member changeover.

In conclusion, call-playback is the most efficient method of locating mesite groups, but its accuracy as a census tool requires assessment, in particular with regard to assumptions affecting density calculation. For this reason extrapolations of density to regional populations (as attempted here) should be regarded as provisional only.

\section{Status of the White-breasted Mesite}

White-breasted Mesites do not appear to be particularly rare in some areas of undisturbed or slightly disturbed forest. The estimated population of between 3,000 and 19,000 individuals in the Menabe region, and of between 6,000 and 26,000 in Ankarafantsika, means that the species is not immediately threatened. However, a substantial proportion of these populations live in areas where productivity and density appear to be low, and might thus be acting as "sinks" 
(Howe et al. 1994). Ankarana and Analamera probably hold only relict populations and the status of eastern rainforest populations is completely unknown.

Much of the White-breasted Mesite's forest range is legally protected. The following summary of protected areas where the species is found is taken from Nicoll and Langrand (1989). Entry to Ankarafantsika Strict Nature Reserve is theoretically forbidden to all except scientific workers and Water and Forest Department officals. Ankarana, Analamera and Andranomena Special Reserves have laws forbidding burning, exploitation, deforestation, cultivation and hunting within them, but access is permitted under certain restrictions. Ampijoroa Forestry Station's legal status is unclear. Classified forests such as Ankarafantsika Forest Reserve and Ampataka have individual statutes which generally permit limited exploitation but prevent cultivation. Analabe (north of Beroboka, Menabe; Figure 2) has no legal protection, and large areas of forest within the concession were cleared for the plantation of sisal by the concession-holder.

In practice hunting and limited exploitation of forest products within designated forests are widespread. Deforestation for cultivation has affected especially Analamera (Hawkins et al. 1990) and Andranomena, and illegal timber extraction is practised in Ankarafantsika (M. Rabemazava verbally 1992) and Ankarana (Hawkins et al. 1990). In general hunting, subsistence exploitation and clearance of forest for cultivation occur near villages, and timber extraction in more remote areas, away from authority (J.-C. Favre verbally 1993).

\section{Habitat quality and its effects}

Tables 2 and 3 show that mesites occur at highest densities in undegraded sand forest at Ampijoroa, followed in order by approximately equal densities in logged forest near rivers at Kirindy and valley forest at Ampijoroa, in somewhat lower densities in logged and unlogged forest far from rivers at Kirindy, and in lowest densities in degraded sand forest at Ampijoroa and in Andranomena.

As has been pointed out by van Horne (1983), density may not in itself be a good indicator of the productivity of habitat. Mesite group size (and by implication productivity) is significantly lower in forest far from rivers (both logged and unlogged) compared with that close to rivers in Kirindy, and lower in degraded sand forest than in either primary sand forest or valley forest at Ampijoroa. Group size seems thus to follow density in indicating habitat quality, with the exceptions of unlogged forest close to rivers at Kirindy, and at Andranomena for which sample sizes are too small for analysis. Low density at Andranomena and possibly in unlogged forest close to rivers at Kirindy may be due to hunting. Overall it seems that, in the southern part of the species's range, forest far from rivers and probably heavily hunted forest is low-quality habitat, and in the north degraded sand forest is lower quality than undisturbed sand forest.

There are several possible explanations for the variation in quality of sites for mesites. High-quality sites may be richer in food, offer better protection from predators or provide a more suitable microclimate. Mesite foraging sites are characterized by a strong tendency to a dense shrub layer and a weaker but still positive tendency to a complete canopy (Hawkins 1993). This may account for the high density of mesites found in logged forest close to rivers at Kirindy (Table 2), as the shrub layer there is denser than in adjacent unlogged forest, 
which is on relatively shallow calcareous soil and has a thin shrub layer and almost exclusively deciduous canopy. Olson and Andriamiadana (in press) show that at Kirindy the number of individuals and total biomass of litter invertebrates (including spiders, crickets and beetles, all eaten by mesites) are higher in forest blocks close to rivers than elsewhere, and that species richness (but not number of individuals or biomass) was higher in logged forests than unlogged forest. This suggests that food for mesites may be more abundant and more diverse in logged forest near rivers.

Appert (1985) noted that mesites require some shade during the hottest part of the day, an observation with which my studies agree; the absence of such shade, particularly in the dry season, in calcareous areas of Kirindy seems likely to be important in governing mesite distribution regardless of logging status. Heat-stress is invoked as an important element in habitat selection of forestinterior birds (Bertin 1977, Karr 1977, Bell 1982, Johns 1986) but there seem to be few data to support this explanation.

\section{The impact of fragmentation}

Collar and Stuart (1985) summarized the White-breasted Mesite's status. The present study reinforces their observation that its restricted range must be a permanent source of concern, particularly as the species appears to be absent from areas of apparently suitable habitat at Ambinda, Namoroka and Marofihitse. This observation refutes the statement of Milon et al. (1973) that it occurs "in all western Madagascar". White-breasted Mesites have low dispersal powers, as they avoid forest gaps and are very unwilling to fly. The rate of repopulation of sites separated by more than a few hundred metres from a source population is likely to be low. It may be that this accounts for the species's patchy distribution: forests which have been cleared in the past and which are remote from others (for instance as appears to be the case at Ambinda) will not be recolonized even if complete regeneration takes place, and this may have happened to much of the forest in the west of Madagascar over the last 1,000 years. Forest in the Menabe region (Figure 2) is already virtually divided into four separate blocks, and it is doubtful if significant gene-flow occurs between them. The same applies to the western part of Ankarafantsika Forest Reserve (Figure 7).

\section{The impact of deforestation}

Collar and Stuart (1985) suggested that deforestation ranks among the current threats to the species. The negative effects of clear-cutting and burning for agriculture on mesites are unequivocal. The land is completely cleared and on present evidence will regenerate very slowly if at all (Cabalzar 1990, CFPF 1992). White-breasted Mesites and most other western Malagasy forest birds are eliminated by this, and mesites at least are so poor at dispersing they may never recolonize regenerated areas. In the Andranomena area, forest clearance for crop plantation has now been reduced significantly by developing cash markets for crops such as peanuts grown in old forest clearings (Cabalzar 1990).

The situation is more complicated in the case of selective logging, which in the northern sector of the Menabe region in particular is already widespread 
and likely to increase (J.-C. Favre verbally 1993). Hawkins and Wilmé (in press) show that the effect of selective exploitation at Kirindy on forest close to rivers is to reduce the percentage canopy cover and to increase the density of the shrub layer. Selective logging, at least of the type conducted at Kirindy, may have the effect of improving habitat quality for mesites, at least in the short term, by improving protection from raptors and increasing the diversity of potential insect prey.

Other changes that come with exploitation (increased hunting, increased fire likelihood and frequency) are likely to have negative consequences for mesites. At Kirindy, the presence of foresters in what would otherwise be a remote and inaccessible forest block has undoubtedly resulted in hunting of mesites and other animals.

\section{The impact of fire}

The first fire passing through a western Malagasy forest often burns only the leaf-litter, killing a few canopy trees (M. Rabemazava verbally 1991). However, a second fire may be much hotter, consuming dead standing wood left by the first and seriously affecting the canopy. Thus, forest that burnt in 1983 at Ampijoroa still supports mesites, although the group size in burnt forest is significantly smaller than group size in adjacent undisturbed forest, suggesting that territories in burnt forest are occupied by subordinate or immature birds. A second fire in a part of the same forest in 1987 left only $10 \%$ of canopy trees standing; the rest of this area is now covered in very dense shrub layer and supports no mesites.

Bush fires are used to promote herbaceous growth for cattle and occur in abundance throughout western Madagascar; they only rarely penetrate forest but even one fire every 50 years may be sufficient to eliminate forest eventually. The extent to which western forest is being destroyed by fire is extremely difficult to determine. Ampijoroa and the adjoining Integral Reserve and Forest Reserve of Ankarafantsika are continually threatened by bush fires, especially during the dry season ( $R$. Albignac verbally 1992), and sand forest (with high densities of mesites) is probably the most vulnerable to fire. Forest in the Menabe region does not appear to be as susceptible to bush fires, for reasons as yet unclear.

\section{The impact of nest predation}

Some species of forest-interior bird show reduced productivity near forest edges (such as those produced by logging), caused by increased nest predation or parasitism by forest-edge species (Brittingham and Temple 1983, Karr 1990), and forest birds may select nest sites likely to be concealed from predators (Kelly 1993). Mesites appear to make no special effort to hide nests in dense vegetation, but their use of very few sticks, placed on branches in relatively open understorey, makes finding them very difficult (pers. obs.). Avian nest predators and parasites such as Madagascar Lesser Cuckoo Cuculus rochii, Madagascar Coucal Centropus toulou and Hook-billed Vanga Vanga curvirostris are commoner near forest edges in western Madagascar (A.F.A.H. unpublished data), but their effect on mesites is unknown. 
Collar and Stuart (1985) suggested that introduced rats in particular are likely to pose a threat to mesites. Black rats Rattus rattus are greatly outnumbered in western forests by native rodents (V. Randrianzafy verbally 1993) and at Kirindy black rats are very rare, and the few so far caught are restricted to the immediate vicinity of the river-bed ( $P$. Kappeler verbally 1993). In degraded forest isolates south of Andranomena, black rats are abundant in savanna but rarely penetrate more than $50 \mathrm{~m}$ into the forest (J. Ganzhorn verbally 1993). It thus seems unlikely that rats materially affect productivity of mesites except in those groups living on forest margins, although even low densities of rats near productive mesite habitat near rivers might be very destructive. At Kirindy there are two species of partly arboreal native rodent, and at Ampijoroa three (Nicoll and Langrand 1989); it is not known what effect these species have on mesites, nor whether they are likely to be more of a threat than introduced rats. The only recorded predation on a mesite nest was by an abundant forest snake Leioheterodon madagascariensis (pers. obs.).

The question of nest predation warrants study in more depth, particularly in relation to depressed productivity near forest edges, as western forests become more fragmented. Adult mesites also seem vulnerable to avian predators: Henst's Goshawk Accipiter henstii, a local but not uncommon species at Kirindy and Ampijoroa, has been recorded catching White-breasted Mesites (Langrand 1990) and on several occasions on call-playback surveys this raptor was apparently attracted by the mesite song. On one occasion, over a ten-minute period a Henst's Goshawk overflew the observer each time the tape was played, obviously trying to locate the source of the song. A dense shrub layer would seem to be the most effective protection from this and other avian raptors.

\section{The impact of dogs and hunting}

Langrand (1990) implied that dogs cause mesite mortality near villages. However, there appears to be no evidence of direct predation. Informal interviews with local hunters at Marofandilia (near Andranomena Special Reserve) established that mesites are easily killed with a slingshot, and that hunters use dogs to flush the birds into trees before taking aim. However, even in these instances birds are probably only taken opportunistically. Hunting (at least of mesites) seems to be at a lower level in Kirindy and Ampijoroa than at Andranomena and, as the latter forest seems structurally similar to that at Kirindy, it is possible that hunting is the reason for the species's rarity there. Mesites in Andranomena and in edge forest at Ampijoroa were much more wary of people than those at Kirindy or in JBA at Ampijoroa; this sensitization may have been caused by repeated hunting activity.

Hunting is likely to increase with fragmentation of habitat, which may facilitate access by hunters. Local extinction of populations in small fragments or in areas close to villages (as seems to have happened in southern Andranomena already) will certainly be hastened by hunting.

\section{The conservation status of the White-breasted Mesite}

The species's limited distribution, poor recolonization potential and susceptibility to hunting seriously compromise its future, whatever its current numerical 
status or response to limited sustainable exploitation. Clearly, population levels could decline very rapidly if fire or overexploitation of habitat causes the loss of suitable forest, particularly if this happens in areas of high productivity. This might then be followed by increased hunting and possibly nest predation. The species's long-term survival, as with as other western Malagasy forest endemic animals, such as the flat-tailed tortoise Acinyxis planicauda and the giant jumping rat Hypogeomys antimena, depends on intervention to reduce human reliance on forest land for cultivation, the development of bushfire reduction programmes, and a revaluation of degraded agricultural land next to forest. In addition, further investigation of the scale of commercial exploitation, particularly in the Menabe region, is also necessary.

\section{Acknowledgements}

This project was funded by the British Ecological Society, the British Ornithologists' Union, the Flora and Fauna Preservation Society (Oryx 100\% Fund), Jersey Wildlife Preservation Trust, the Lindeth Charitable Trust, the People's Trust for Endangered Species, and World Wide Fund for Nature (Madagascar) Ecology Training Programme. I am very grateful to all the these agencies. British Airways - Assisting Nature Conservation provided return flights between London and Nairobi: many thanks to $R$. Hall.

The work was undertaken within a protocol of collaboration established between J. Ganzhorn of the University of Tübingen, Germany, and the Tripartite Commission of the Malagasy Government, under the auspices of B. Rakotosamimanana of the Ministère d'Enseignement Supérieur. I am grateful to the Tripartite Commission for the opportunity to work in Madagascar, and to J. Ganzhorn for his guidance and help. Much logistical help and hospitality was given by the staff of the CFPF and SAF in Morondava, for which I am very grateful. Collaboration with E. Rakotovao, of the Circonscription des Eaux et Forêts in Morondava, was vital to the project. The Chef de Réserve at Ampijoroa, M. Rabemazava, provided much assistance and advice. N. Quansah, D. Reid, P. de Valois, A. Randriamanantena, H. Randrianasolo, L. Andriamampianina and $\mathrm{M}$. Andriamboevonjy were very generous with hospitality, company and help with fieldwork. Thanks go to $S$. $\mathrm{O}^{\prime}$ Connor and $O$. Langrand (WWF-Madagascar) for advice and the loan of equipment. I am very grateful for methodological advice and encouragement from J. Sears (Royal Society for the Protection of Birds), R. J. Fuller (British Trust for Ornithology), M. R. W. Rands, A. Gretton, J. H. Fanshawe and C. J. Bibby (BirdLife International) and L. Durrell (Jersey Wildlife Preservation Trust). J. Durbin improved a draft of this paper.

\section{References}

Appert, O. (1985) Zur Biologie der Mesitornithiformes (Nakas oder Stelzenrallen) Madagaskars und erste fotografische Dokumente von Vertretern der Ordnung. Orn. Beob. 82: $31-54$.

Bell, H. L. (1982) A bird community of lowland rainforest in New Guinea III. Vertical distribution of the avifauna. Emu 82: 143-162. 
Bertin, R. I. (1977) Breeding habitats of the Wood thrush and Veery. Condor 79: 303-311.

Bibby, C. J. and Buckland, S. T. (1987) Bias of bird census results due to detectability varying with habitat. Acta Oecol. 8: 103-112.

Brittingham, M. C. and Temple, S. A. (1983) Have cowbirds caused forest songbirds to decline? BioScience 33: 31-35.

Buckland, S. T., Anderson, D. R., Burnham, K. P. and Laake, J. L. (1993) Distance sampling: estimation of abundance of biological populations. London: Chapman and Hall.

Cabalzar, G. (1990). Projet SAF-Cote Ouest. Akon'ny Ala 4: 10-26.

CFPF (1991) Sentiers Botaniques 1 et 2. Morondava, Madagascar: Centre de Formation Professionelle Forestière.

CFPF (1992) Rapport Annuel des Activités; 1991. Morondava, Madagascar: Centre de Formation Professionelle Forestière.

Chauvet, B. (1972) The forests of Madagascar. Pp.191-199 in R. Battistini and G. RichardVindard, eds. Biogeography and ecology in Madagascar. The Hague: W. Junk (Monogr. Biol. 21).

Collar, N. J. and Stuart, S. N. (1985) Threatened birds of Africa and related islands: the IUCN/ ICBP Red Data Book. Third edition, part 1. Cambridge, U.K: International Council for Bird Preservation.

Collar, N. J., Crosby, M. J. and Stattersfield, A. J. (1994) Birds to watch 2: the world list of threatened birds. Cambridge, U.K.: BirdLife International (BirdLife Conservation Series 4).

Cuvelier, A. (1990) Objectifs du CFPF. Morondava, Madagascar: Centre de Formation Professionelle Forestière.

DEF/UNDP/UNESCO (undated) Cartes d'Ankarafantsika. Projet DEF/UNDP/UNESCO MAG/88/oo7, Ankarafantsika. Unpublished.

Ducenne, H., Schroff, U. and Narson, A. (1988) Carte des végétations établie à partir des scènes SPOT (3o.8.86) et SOJUZ (29.5.87) et des observations du SAF Côte-Ouest, Décembre 1988. Morondava: SAF Côte-Ouest.

Ganzhorn, J. U., Ganzhorn, A. W., Abraham, J.-P., Andriamaro, L. and Ramanjatovo, A. (1989) The impact of selective logging on lemur populations in western Madagascar. Primate Report 25: 13.

Ganzhorn, J. U., Ganzhorn, A. W., Abraham, J.-P., Andriamaro, L. and Ramanjatovo, A. (1990) The impact of selective logging on forest structure and tenrec populations in western Madagascar. Oecologia 84: 126-133.

Ganzhorn, J. U. and Sorg, J. P., eds. (in press) Economy and ecology of a tropical dry forest in Madagascar. Heidelberg: Springer Verlag.

Hawkins A. F. A. (1993) Relationships among vegetation structure and White-breasted Mesite presence and foraging site choice. Proc. 8 Pan-Afr. Orn. Congr.: 155-163.

Hawkins, A. F. A., Chapman, P., Ganzhorn, J. U., Bloxam, Q., Tonge, S. and Barlow, S. (1990) Vertebrate conservation in Ankarana Special Reserve, northern Madagascar. Biol. Conserv. 54: 83-110.

Hawkins, A. F. A. and Wilmé, L. (in press) Effects of logging on forest birds. In J. U. Ganzhorn and J. P. Sorg, eds. Economy and ecology of a tropical dry forest in Madagascar. Heidelberg: Springer Verlag.

van Horne, B. (1983) Density as a misleading indicator of habitat quality. J. Wildl. Mgmt. 47: 893-901.

Howard, P. C. (1991) Nature conservation in Uganda's tropical forest reserves. Cambridge, U.K., and Gland, Switzerland: International Union for Conservation of Nature and Natural Resources.

Howe, R. W., Davis, G. J. and Mosca, V. (1991) The demographic significance of "sink" populations. Biol. Conserv. 57: 239-255. 
Janzen, D. H. (1988) Tropical dry forests: the most endangered major tropical ecosystem. Pp.130-137 in E. O. Wilson, ed. Biodiversity. Washington, D.C.: National Academy Press.

Jenkins, M. D., ed. (1987) Madagascar: an environmental profile. Cambridge, U.K., and Gland, Switzerland: International Union for Conservation of Nature and Natural Resources.

Johns, A. D. (1986) Effects of selective logging on the ecological organisation of a peninsular Malaysian rainforest avifauna. Forktail 1: 65-79.

Johns, A. D. (1989) Recovery of a Peninsular Malaysian rainforest avifauna after selective logging: the first twelve years. Forktail 4: 89-105.

Johns, A. D. (1991) Responses of Amazonian rain forest birds to habitat modification. J. Trop. Ecol. 7: 417-437.

Karr, J. R. (1977) Ecological correlates of rarity in a tropical forest bird community. Auk 94: $240-247$.

Karr, J. R. (1990) Avian survival rates and the extinction process on Barro Colorado Island, Panama. Conserv. Biol. 4: 391-397.

Kelly, J. P. (1993) The effect of nest predation on habitat selection by Dusky flycatchers in Limber pine-juniper woodland. Condor 95: 83-93.

Kelly, J. R. and Harwell, M. A. (1990) Indicators of ecosystem recovery. Envir. Mgmt. 14: 527-545.

Laake, J. L., Buckland, S. T., Anderson, D. R. and Burnham, K. P. (1993) DISTANCE User's Guide V2.o. Fort Collins, CO: Colorado Cooperative Fish and Wildlife Research Unit, Colorado State University.

Lambert, F. R. (1992) The consequences of selective logging for Bornean lowland forest birds. Pp.443-457 in A. G. Marshall and M. D. Swaine, eds. Tropical rain forest: disturbance and recovery. London: The Royal Society.

Langrand, O. (1990) Guide to the birds of Madagascar. New Haven: Yale University Press.

Lavauden, L. (1931) Note préliminaire sur les oiseaux appartenant aux genres Mesoenas et Monias. Alauda 3: 395-400.

Lavauden, L. (1937) Supplement to Volume XII: Oiseaux, by A. Milne-Edwards and A. Grandidier (1879-1885) Histoire physique, naturelle et politique de Madagascar. Paris: Société d'Editions Géographiques, Maritimes et Coloniales.

Levings, S. C. and Windsor, D. M. (1984) Litter moisture content as a determinant of litter arthropod distribution and abundance during the dry season on Barro Colorado Island. Biotropica 16: 125-131.

Milon, P., Petter, J.-J., and Randrianasolo, G. (1973) Faune de Madagascar, 35: Oiseaux. Tananarive and Paris: ORSTOM/CNRS.

Murphy, P. G. and Lugo, A. (1986) Ecology of dry tropical forest. Ann. Rev. Ecol. Syst. 17: $67-88$.

Marion, W. R., O'Meara, T. E. and Maehr, D. S. (1981) Use of playback recordings in sampling elusive or secretive birds. Chapter 20 in C. J. Ralph and V. A. Scott, eds. Estimating the numbers of terrestrial birds. Cooper Ornithological Society (Studies in Avian Biology 6).

Nicoll, M. E., and Langrand, O. (1989) Madagascar: revue de la conservation et des aires protégées. Gland, Switzerland: World Wide Fund for Nature.

Olson, D. M. and Andriamiadana, A. (in press) The impact of selective logging on the leaf litter invertebrate community of a tropical dry forest in western Madagascar. In J. Ganzhorn and J. Sorg, P., eds. Economy and ecology of a tropical dry forest in Madagascar. Heidelberg: Springer Verlag.

Ramaromanga, S. (1993) Zones périphériques et les pressions sur les aires protégées. In Atelier sous-régional sur "les populations rurales et les aires protégées", Morondava, 14-18 December 1992. Antananarivo: UNESCO/ANGAP. 
Rand, A. L. (1936) The distribution and habits of Madagascar birds. Bull. Amer. Mus. Nat. Hist. 72: 143-499.

Sibley, C. G. and Ahlquist, J. E. (1990) The phylogeny and classification of birds: a study in molecular evolution. New Haven: Yale University Press.

Smith, A., Moore, D. and Horning, N. (1991) Madagascar biodiversity planning service. Pilot Study. Armidale, Australia: University of New England.

Spellerberg, I. F. (1991) Monitoring ecological change. Cambridge, U.K.: Cambridge University Press.

Strahl, S. D. and Grajal, A. (1991) Conservation of large avian frugivores and the management of Neotropical protected areas. Oryx 25: 50-55.

Thiollay, J.-M. (1992) Influence of selective logging on bird species diversity in a Guianan rain forest. Conserv. Biol. 6: 47-62.

Thompson, P. M. and Evans, M. I. (1992) The threatened birds of Ambatovaky Special Reserve, Madagascar. Bird Conserv. Internatn. 2: 221-237.

A. F. A. HAWKINS

10 Lodway Gardens, Pill, Bristol BSzo oDL, U.K. 